Article

\title{
Supplementation of Microbial and Fungal Phytases to Low Protein and Energy Diets: Effects on Productive Performance, Nutrient Digestibility, and Blood Profiles of Broilers
}

\author{
Youssef A. Attia ${ }^{1, *(\mathbb{D}}$, Fulvia Bovera ${ }^{2, *}$, Mohammed A. Al-Harthi ${ }^{1}$, Abd El-Razek E. Tag El-Din ${ }^{3}$ \\ and Walaa Said Selim ${ }^{3}$ \\ 1 Department of Agriculture, Faculty of Environmental Sciences, King Abdulaziz University, \\ P.O. Box 80208, Jeddah 21589, Saudi Arabia; malharthi@kau.edu.sa \\ 2 Department of Veterinary Medicine and Animal Production, University of Napoli Federico II, \\ 80137 Napoli, Italy \\ 3 Animal and Poultry Production Department, Faculty of Agriculture, Damanhour University, \\ Damanhour 22516, Egypt; a.tageldin@gmail.com (A.E.-R.E.T.E.-D.); drwalaaselim@yahoo.com (W.S.S.) \\ * Correspondence: yaattia@kau.edu.sa (Y.A.A.); bovera@unina.it (F.B.); Tel.: +96-656-857-5961 (Y.A.A.); \\ +39-081-253-6497 (F.B.)
}

Citation: Attia, Y.A.; Bovera, F.; Al-Harthi, M.A.; El-Din, A.E.-R.E.T.; Said Selim, W. Supplementation of Microbial and Fungal Phytases to Low Protein and Energy Diets: Effects on Productive Performance, Nutrient Digestibility, and Blood Profiles of Broilers. Agriculture 2021, 11, 414. https:/ / doi.org/10.3390/agriculture 11050414

Academic Editor: Vito Laudadio and Vincenzo Tufarelli

Received: 9 April 2021

Accepted: 29 April 2021

Published: 4 May 2021

Publisher's Note: MDPI stays neutral with regard to jurisdictional claims in published maps and institutional affiliations.

Copyright: (c) 2021 by the authors. Licensee MDPI, Basel, Switzerland. This article is an open access article distributed under the terms and conditions of the Creative Commons Attribution (CC BY) license (https:/ / creativecommons.org/licenses/by/ $4.0 /)$.

\begin{abstract}
To evaluate in possible use of phytases for improving the utilization of low protein and energy diets, 420, one-day-old chicks were distributed among 7 groups ( 5 replicates of 12 chicks /group). During the starter (1-35 day), grower (37-56 day), and finisher (57-64 day) periods, the control group fed diets containing $21.2 \%$ crude protein (CP)-2947 Kcal/ $\mathrm{kg}$ metabolizable energy (ME), $19.6 \mathrm{CP}-3023$ $\mathrm{ME}$ and 18.0 CP-3100 ME, respectively. The three low-CP groups received diets isocaloric but with $-1 \%$ CP than the control, while the three low-CPME groups fed diets with $-1 \%$ CP and -100 Kcal than the control. In addition, the low-CP and low-CPME groups were supplemented with 0 (low-CP_uns and low-CPME_uns), $500 \mathrm{U} / \mathrm{kg}$ of an Aspergillus niger (low-CP_AP and low-CPME_AP) or $500 \mathrm{FTU} / \mathrm{kg}$ of an Escherichia coli phytase (low-CP_EP and low-CPME_EP), respectively. Low-CP and low-CPME diets decreased $(p<0.01)$ the intake of feed as well as the protein and metabolizable energy conversion ratios in comparison to the control group. In general, phytases lowered $(p<$ $0.01)$ the intake of feed, protein, and energy, but bacterial phytase showed a higher $(p<0.01)$ effect than $A$. niger one. The diets with low-CP and low-CPME levels decreased $(p<0.01)$ the amount of the excreta nitrogen. The supplementation of phytases had similar effects on digestibility of nutrients, carcass traits, bone mineralization and blood biochemistry. The supplementation of $A$. niger increased abdominal fat deposition of compared low-CPME diet compared to low-CPME_uns diet. All diets showed similar production index allowing the use of low-CPME diet when phytases was supplemented.
\end{abstract}

Keywords: phytase; broiler; low energy and protein diets; productive performance; blood profiles

\section{Introduction}

One of the challenges in poultry production is to reduce the level of proteins and energy in the diets, to improve the sustainability and reduce the costs of the production. A possible approach could be the use of diets containing lower crude protein (CP) and metabolizable energy (ME) compared to the standard corn-soybean meal-based diets. However, the use of low-CP and ME diets can decrease body weight gain, impair feed conversion ratio, and increase fat deposition [1]. The low-CP diets can be improved by essential amino acids supplementation, avoiding the impairment of the growth performance also under poor sanitary conditions [2]. However, Liu et al. [3] indicated that balancing amino acids requirements of poultry is problematic, and an alternative promising strategy could be condensing starch: protein ratios. This goal could be reached by using enzyme supplementations. 
The use of phytase is an exciting approach as this enzyme had a positive effect on mineral and non-mineral nutrient availability. The effects of phytase are linked to its activity on phytic acid: removing this anti-nutritional factor improves the nutritional value of the diet in terms of mineral bioavailability and energy and protein efficiency [4]. In the last years, there were several evidences of the effect of phytase on improving nutrient availability. Lu et al. [5] observed that phytase increased the expression of GLUT2 in pigs, and this can indicate an upregulation of glucose absorption from the intestine by phytase. Ren et al. [6] observed that increasing phytase (E. coli) levels in the diets of pigs increased $(p<0.05)$ the apparent ileal digestibility of some amino acids (Arg, Lys, His, Asp, Ile, Trp, and Glu). Babatunde et al. [7] showed that phytases from Aspergillus niger, A. oryzae and Trichoderma reesei can improve growth performance, nutrient, and mineral digestibility of broiler. Ennis et al. [8] evaluated the inclusion of phytase and carbohydrase as a possible strategy to optimize low-energy diets in male broiler and observed that supplementing phytase at a $1500 \mathrm{FTU} / \mathrm{kg}$ enhances broiler performance by improving 28 to 44 and 0 to 44 days FCR by 4 and 3 points, respectively.

The phytases commonly used in poultry nutrition can have different origin, and thus mode of action. Under a chemical point of view, the phytase is an enzyme, a phosphatase, able to hydrolyze phosphate groups. According to the position of the phosphate group in the myo-inositol ring, they can be classified as 3-phytase and 6-phytase [9]. Phytases can differ in terms of optimal $\mathrm{pH}$, resistance to digestive enzymes, and thermostability [10]. Standing these considerations, it is clear that there are different commercial products containing different kinds of phytase. This paper aimed to compare the effect of 3 and 6-phytase supplementation on productive performance, meat quality, nutrient utilization, and production cost of colored slow-growing broilers fed corn-soybean diets with low $\mathrm{CP}$ and ME concentrations.

\section{Materials and Methods}

All the animals were treated according to the principles of the animal welfare stated by the Directive 63/2010/EEC regarding the protection of the animals used for experimental and other scientific purposes. The experimental procedures were approved by the Ethical Animal Care and Use Committee of the Department of Veterinary Medicine and Animal Production of the University of Napoli Federico II, Italy (prot. N. 2017/0017676).

\subsection{Experimental Chickens Design and Diets}

During 1 to 64 day of age, 420, one-day-old colored slow-growing broiler chicks from Sasso strain (sex ratio 1:1) were divided into 7 groups (5 replicates of 12 chicks each). Each replicate was housed in a floor pen $(1.0 \mathrm{~m} \times 1.0 \mathrm{~m} / \mathrm{pen})$ with a rice hulls litter. The groups were fed different starter (1-35 d), grower (37-56 d) and finisher (57$64 \mathrm{~d}$ ) mash diets according to the broiler's age. Along the experimental period, the control group was fed three diets with the following contents of crude protein $(\mathrm{CP})$ and metabolizable energy (ME): $21.2 \%$ and $2947 \mathrm{kcal} / \mathrm{kg} ; 19.6 \%$ and $3023 \mathrm{kcal} / \mathrm{kg} ; 18.0 \%$ and $3100 \mathrm{kcal} / \mathrm{kg}$, respectively, in the starter, grower, and finisher period. The 3 low-CP groups were fed diets with similar ME contents than the control but in which $\mathrm{CP}$ percentages were reduced by around 1\%. The 3 low-CP groups were submitted to 3 different dietary treatments as follows: low-CP unsupplemented group (low-CP_uns); low-CP fungal phytase group, supplemented with $500 \mathrm{U} / \mathrm{kg}$ of a diet of a fungal phytase (low-cp_FP group, Aspergillus niger phytase, Natuphos ${ }^{\circledR}$ BASF, Germany) and low-CP bacterial phytase group, supplemented with 500 FTU/kg diet of a bacterial phytase (low-CB_BP group, Escherichia coli phytase, Phyzyme ${ }^{\circledR}$ Danisco Animal Nutrition). The other 3 groups were fed low-CP and ME diets (low-CPME) in which the percentage of protein and the amount of energy were reduced by $1 \%$ and $100 \mathrm{kcal}$, respectively, in comparison to the control diets. The 3 low-CPME groups were submitted to the same treatments as the low-CP groups: low-CPME_uns, low-CPME_FP and low-CPME_BF groups. 
The diets (Table 1) were formulated according to NRC [11]. The percentages of Ca and available $\mathrm{P}$ of the diets supplemented with phytase were not corrected for the phytase equivalent value to test the effect of the two phytases on the utilization of protein and energy when sufficient levels of $\mathrm{Ca}$ and $\mathrm{P}$ are available in the diets. Chemical analyses of diets agreed to Association of Official Analytical Chemists (AOAC) [12]. Diets and water were administered ad libitum along the trial. Chicks were submitted to a light:dark cycle of 23:1 along the entire period of the trial. Vaccinations and medical care were in line with the common veterinary practice for broilers. All the chicks have been raised under the same managerial, hygienic, and environmental conditions.

Table 1. Ingredients and chemical-nutritional characteristics of the diets used along the trial.

\begin{tabular}{|c|c|c|c|c|c|c|c|c|c|}
\hline & \multicolumn{3}{|c|}{ Starter Diets } & \multicolumn{3}{|c|}{ Grower Diets } & \multicolumn{3}{|c|}{ Finisher Diets } \\
\hline & Control & Low-CP & $\begin{array}{c}\text { Low- } \\
\text { CPME }\end{array}$ & Control & Low-CP & $\begin{array}{c}\text { Low- } \\
\text { CPME }\end{array}$ & Control & Low-CP & $\begin{array}{l}\text { Low- } \\
\text { CPME }\end{array}$ \\
\hline & \multicolumn{9}{|c|}{ Ingredients g/kg } \\
\hline Yellow corn & 583.5 & 585.0 & 585.0 & 626.5 & 626.5 & 626.5 & 630.0 & 630.0 & 630.0 \\
\hline Soybean meal & 320.0 & 300.0 & 300.0 & 275.0 & 255.0 & 255.0 & 282.5 & 260.0 & 260.0 \\
\hline Fish meal & 30.0 & 30.0 & 30.0 & 30.0 & 30.0 & 30.0 & - & - & - \\
\hline Limestone & 10.0 & 10.0 & 10.0 & 9.00 & 9.00 & 9.00 & 9.00 & 9.00 & 9.00 \\
\hline Dicalcium phosphate & 18.0 & 18.0 & 18.0 & 16.0 & 16.5 & 16.5 & 17.00 & 17.0 & 17.0 \\
\hline Vit + Min Premix ${ }^{1}$ & 3.00 & 3.00 & 3.00 & 3.00 & 3.00 & 3.00 & 3.00 & 3.00 & 3.00 \\
\hline $\mathrm{NaCl}$ & 3.00 & 3.00 & 3.00 & 3.00 & 3.00 & 3.00 & 3.00 & 3.00 & 3.00 \\
\hline DL-Methionine & 1.50 & 1.50 & 1.50 & 1.50 & 1.50 & 1.50 & 1.50 & 1.50 & 1.50 \\
\hline L-Lysine (HCl) & 1.00 & 1.00 & 1.00 & 1.00 & 1.00 & 1.00 & 1.00 & 1.00 & 1.00 \\
\hline Vegetable oils & 30.0 & 37.0 & 22.0 & 35.0 & 42.0 & 26.5 & 53.0 & 61.0 & 46.00 \\
\hline \multirow[t]{2}{*}{$\begin{array}{l}\text { Washed building } \\
\text { sand }\end{array}$} & - & 11.5 & 26.5 & - & 12.5 & 28.0 & - & 14.5 & 29.50 \\
\hline & \multicolumn{9}{|c|}{ Chemical-Nutritional Characteristics } \\
\hline Dry matter ${ }^{2}$ & 89.61 & 89.70 & 89.53 & 89.87 & 89.63 & 89.76 & 89.57 & 89.69 & 89.84 \\
\hline $\mathrm{ME}, \mathrm{MJ} / \mathrm{Kg}^{3}$ & 12.34 & 12.36 & 11.95 & 12.66 & 12.66 & 12.24 & 12.94 & 12.95 & 12.54 \\
\hline $\mathrm{CP} \%{ }^{2}$ & 21.03 & 20.01 & 20.02 & 19.49 & 18.51 & 18.84 & 17.80 & 16.79 & 16.81 \\
\hline Methionine $\%{ }^{3}$ & 0.51 & 0.50 & 0.50 & 0.49 & 0.48 & 0.48 & 0.44 & 0.42 & 0.42 \\
\hline SAA $\%^{3}$ & 0.85 & 0.82 & 0.82 & 0.80 & 0.78 & 0.78 & 0.74 & 0.71 & 0.70 \\
\hline Lysine $\%{ }^{3}$ & 1.24 & 1.19 & 1.19 & 1.13 & 1.08 & 1.08 & 1.00 & 0.94 & 0.94 \\
\hline Calcium \% 3 & 0.99 & 0.99 & 0.99 & 0.90 & 0.90 & 0.90 & 0.81 & 0.80 & 0.80 \\
\hline Av. $\mathrm{P} \%{ }^{3}$ & 0.49 & 0.49 & 0.49 & 0.45 & 0.45 & 0.45 & 0.40 & 0.39 & 0.39 \\
\hline Crude fat $\%{ }^{2}$ & 5.47 & 5.98 & 4.70 & 6.21 & 6.74 & 5.26 & 7.63 & 7.98 & 6.97 \\
\hline Crude fiber $\%{ }^{2}$ & 3.47 & 3.34 & 3.39 & 3.31 & 3.24 & 3.20 & 3.33 & 3.24 & 3.26 \\
\hline Ash $\% 2$ & 9.24 & 10.02 & 11.21 & 9.30 & 10.28 & 10.19 & 9.18 & 10.19 & 11.63 \\
\hline NFE \% ${ }^{2}$ & 60.79 & 60.65 & 60.68 & 61.69 & 61.23 & 62.87 & 62.06 & 61.80 & 61.33 \\
\hline
\end{tabular}

${ }^{1}$ Vit + Min mixture provides per kg: vitamin A (retinyl acetate) $24 \mathrm{mg}$, vitamin $\mathrm{E}$ (dL-tocopheryl acetate) $20 \mathrm{mg}, \mathrm{menadione} 2.3 \mathrm{mg}$, Vitamin D3 (cholecalciferol) $0.05 \mathrm{mg}$, riboflavin $5.5 \mathrm{mg}$, calcium pantothenate $12 \mathrm{mg}$, nicotinic acid $50 \mathrm{mg}$, choline chloride $600 \mathrm{mg}$, vitamin B12 $10 \mathrm{~g}$, vitamin B6 $3 \mathrm{mg}$, thiamine $3 \mathrm{mg}$, folic acid $1 \mathrm{mg}$, d biotin $0.50 \mathrm{mg}$. Trace mineral (milligrams per kilogram of diet): Mn $80 \mathrm{Zn} 60$, Fe 35, Cu 8, Se $0.60 .{ }^{2}$ Analyzed values. ${ }^{3}$ Calculated values. SAA—sulphur-containing amino-acids; NFE-nitrogen-free extracts.

Chicks were individually weighed at the beginning $(1 \mathrm{~d})$ and at the end of the trial (64 d), and body weight gain (BWG) was calculated for the interval 1-64 days of age. At the same days, feed intake has been measured and used to calculate the feed conversion ratio (FCR). The conversion ratios of protein (PCR) and energy (ECR) intakes were calculated as protein (g) or ME (Kcal) necessary to gain one gram of BWG. The survival rate of chicks was monitored daily along the trial.

\subsection{Digestibility Trial}

The coefficients of the apparent nutrient digestibility of the diets were measured at $64 \mathrm{~d}$ of age using 6 male birds per treatment ( 2 broiler from 3 replicates) to avoid the confound 
effect of sex on the digestibility of nutrients, according to Attia et al. [13]. Fecal and urinary nitrogen in excreta samples have been separated according to Jakobsen et al. [14]. The chemical analysis of diets and excreta were determined according to AOAC [12]. The apparent digestibility of the nutrients (dry matter, crude protein, crude fiber, and crude fat) as well as the apparent ash retention were calculated as the ratio between the daily retained nutrient (g/day) and its daily intake $(\mathrm{g})$.

\subsection{Slaughter Test}

At 64 days of age, 6 broilers ( 3 males and 3 females) representative of each replicate were weighed after overnight fasting, and then slaughtered. After plucking and removing the inedible parts (head, legs, and viscera), the whole carcasses (dressed carcasses), and their front and hind parts were weighed. The inner organs (liver, pancreas, and spleen) were weighed, and the intestinal and caecal length were measured and expressed as percentage of the live weight. The total visceral fat, including those located in the abdominal cavity (AF) and surrounding the intestines and heart, were separated, weighed, and expressed as a percentage of live weight.

The right tibia of the 6 slaughtered broilers was separated, cleaned in hexane for $48 \mathrm{~h}$ to remove fat, and thus dried in a heater until constant weight was reached. The length $(\mathrm{mm})$, width $(\mathrm{mm})$, and weight $(\mathrm{g})$ were measured. The percentage of ash in the defatted tibia and the contents of $\mathrm{Ca}$ and $\mathrm{P}$ were measured according to AOAC [12].

At 64 days of age, samples of blood were collected from the wing vein of 6 broilers per treatment (representative of each replicate) in heparinzed tubes. After the separation of plasma by centrifugation (3000 rpm for $15 \mathrm{~min}$ ) the concentrations of $\mathrm{Ca}$, inorganic $\mathrm{P}$ and alkaline phosphatase were measured as described by Attia et al. [15]. The biochemical constituents of blood plasma (total protein, albumin, aspartate aminotransferase (AST), total lipids, cholesterol, and alkaline phosphatase) were measured using specific diagnosing kits (Diamond Diagnostics Company, Egypt) according to Attia et al. [16]. The amount of the globulin was calculated as total protein-albumin.

The European Production Index (EPI) has been calculated according to the following formula: livability $\% \times \mathrm{BW}(\mathrm{kg}) /$ age $(\mathrm{d}) \times \mathrm{FCR} \times 100$.

\subsection{Statistical Analysis}

Before running the statistical analysis, the normality of the error distribution as well as data were tested with Shapiro-Wilks test for normality [17]. The four assumption of ANOVA were validated according to random selection of the samples. In addition, the homogeneity of the variance (homoscedasticity) has been evaluated using the Levene's test [17]. Data were analyzed by the GLM procedure of Statistical Analysis Software [17] using two-way factorial design ( 3 types of diets by 2 types of phytase besides the positive control). The following model was used: Yijk $=\mu+\mathrm{SDi}+\mathrm{DT}+(\mathrm{D} \times \mathrm{DT}) \mathrm{ij}+$ eijk, where Yijk $=$ the dependent variables; $\mu$ = general mean; $\mathrm{SDi}=$ effect of types of diet; $\mathrm{DT} j=$ effect of different phytases; $(\mathrm{D} \times \mathrm{DT}) \mathrm{ij}=$ effect of the interaction between types of dies and phytases; and eijk = random error. The pen (replicate) was the experimental unit for the growing performance, while the single bird was the experimental unit for nutrient digestibility, carcass and meat traits, and blood profiles. Mean differences at $p<0.05$ has been tested using the Student-Newman-Keuls test. Survival rate has been analyzed by chi-square test.

\section{Results}

Table 2 reports the growth performance of slow-growing broilers from 1 to 64 days of age. Both low-CP and low-CPME diets did not affect BWG, final weight, and FCR of broilers; however, these diets similarly reduced $(p<0.01)$ feed and protein intake, and protein and metabolizable energy conversion ratios in comparison to the control group. The energy intake was the lowest $(p<0.01)$ in broilers fed low-CPME diets, followed by low-CP and control diets. The survival rate was not different among groups. The use of 
phytase decreased $(p<0.01)$ feed, protein, and energy intake; in this regard, the E. coli phytase had a greater $(p<0.01)$ effect than $A$. niger one.

Table 2. Growth performance of broilers as affected by diet, type of phytase, and their interaction.

\begin{tabular}{|c|c|c|c|c|c|c|c|c|c|}
\hline & BWG g & $\begin{array}{l}\text { Final } \\
\text { BW g }\end{array}$ & $\begin{array}{c}\text { Feed } \\
\text { Intake } g\end{array}$ & $\begin{array}{l}\text { Protein } \\
\text { Intake g }\end{array}$ & $\begin{array}{c}\text { Energy } \\
\text { Intake } \\
\text { Kcal }\end{array}$ & FCR $g / g$ & PCR g/g & $\begin{array}{c}\text { ECR } \\
\text { Kcal/g }\end{array}$ & Mortality $\mathbf{n}$ \\
\hline & \multicolumn{9}{|c|}{ Effect of Diet } \\
\hline Control & 1757 & 1802 & $4024^{\mathrm{a}}$ & $788^{a}$ & $12130^{\mathrm{a}}$ & 2.29 & $0.621^{a}$ & $7.85^{\mathrm{a}}$ & 0 \\
\hline Low-CP & 1661 & 1694 & $3824^{b}$ & $711^{b}$ & $11531^{b}$ & 2.32 & $0.518^{\mathrm{b}}$ & $7.15^{b}$ & 2 \\
\hline \multirow[t]{2}{*}{ Low-CPME } & 1649 & 1706 & $3813^{b}$ & $709^{b}$ & $11125^{\mathrm{c}}$ & 2.31 & $0.511^{b}$ & $6.86^{\mathrm{b}}$ & 2 \\
\hline & \multicolumn{9}{|c|}{ Effect of Type of Phytase } \\
\hline $\mathrm{FP}$ & 1653 & 1698 & $3825^{a}$ & $710^{\mathrm{a}}$ & $11,335^{a}$ & 2.33 & 0.517 & 7.06 & 1 \\
\hline \multirow[t]{2}{*}{$\mathrm{BP}$} & 1623 & 1667 & $3727^{b}$ & $693^{b}$ & $11,056^{\mathrm{b}}$ & 2.30 & 0.521 & 6.99 & 3 \\
\hline & \multicolumn{9}{|c|}{ Interaction Diet $\times$ Phytase } \\
\hline Control & 1758 & 1802 & $4024^{a}$ & $788^{a}$ & $12,130^{a}$ & 2.29 & 0.621 & 7.85 & 0 \\
\hline Low-CP $\times$ Uns & 1702 & 1748 & $3959^{b}$ & $736^{b}$ & $11,194^{\mathrm{c}}$ & 2.33 & 0.510 & 7.11 & 0 \\
\hline Low-CP $\times$ FP & 1632 & 1675 & $3804^{c, d}$ & $708^{c, d}$ & $11,472^{b}$ & 2.33 & 0.512 & 7.20 & 1 \\
\hline Low-CP $\times$ BP & 1614 & 1659 & $3707^{\mathrm{d}}$ & $690^{\mathrm{d}}$ & $11,178^{c}$ & 2.30 & 0.532 & 7.14 & 1 \\
\hline Low-CPME $\times$ Uns & 1674 & 1720 & $3853^{c}$ & $716^{c}$ & $11,244^{\mathrm{c}}$ & 2.30 & 0.503 & 6.81 & 0 \\
\hline Low-CPME × FP & 1677 & 1722 & $3837^{c}$ & $713^{c}$ & $11,197^{\mathrm{c}}$ & 2.32 & 0.521 & 6.93 & 2 \\
\hline Low-CPME $\times$ BP & 1632 & 1676 & $3748^{\mathrm{d}}$ & $697^{\mathrm{d}}$ & $10,933^{\mathrm{d}}$ & 2.31 & 0.509 & 6.85 & 0 \\
\hline \multirow[t]{2}{*}{ SEM } & 82.8 & 84.5 & 18.5 & 3.41 & 55.0 & 0.037 & 0.012 & 0.146 & - \\
\hline & \multicolumn{8}{|c|}{$p$ Values } & \\
\hline Diet & NS & NS & 0.0001 & 0.0001 & 0.0001 & NS & 0.001 & 0.008 & - \\
\hline Phytase type & NS & NS & 0.0001 & 0.0001 & 0.0001 & NS & NS & NS & - \\
\hline Interaction & NS & NS & 0.005 & 0.005 & 0.004 & NS & NS & NS & - \\
\hline
\end{tabular}

$\mathrm{a}, \mathrm{b}, \mathrm{c}, \mathrm{d}$ means within a column with different superscripts are significantly different $(p<0.05)$; FP—fungal phytase; BP—bacterial phytase; Uns-unsupplemented; SEM—standard error or mean; NS—not significant. Low-CP—low crude protein diet; low-CPME-low crude protein and metabolizable energy diet; FCR—feed conversion ratio; PCR—protein conversion ratio; ECR—energy conversion ratio.

An effect of the interaction diet $\times$ type of phytase was detected $(p<0.01)$ for feed, energy, and protein intake. The control group showed the highest values for the three criteria; however, in the low-CP groups, the use of both phytases similarly decreased $(p<0.01)$ the feed and protein intake, while in the low-CPME diets, bacterial phytase decreased both feed and protein intake in comparison to the other two groups. Regarding the energy intake, in the low-CP groups, the fungal phytase gave the highest values while in the low-CPME diets, fungal phytase gave results not different from the unsupplemented group and higher than the bacterial phytase group.

Mortality was determined as number of dead birds ranged from 0 to 2 birds per experimental group (Table 2), with the highest incidence in the group fed a low-CPME diet supplemented with fungal phytase followed by those fed a low-CP diet supplemented with fungal and bacterial phytase.

The results of digestibility trial (Table 3) showed that low-CPME diets decreased $(p<0.01)$ nitrogen excreta in comparison to the control and low-CP groups. The types of phytases did not affect the dry matter, crude fiber, and crude protein digestibilities as well as the percentage of ash retention and the percentage of nitrogen in the feces. There were no interactions of diet $\times$ type of phytase for the criteria summarized in Table 3 . 
Table 3. Effect of diet, type of phytase, and their interaction on nutrient digestibility, ash retention and fate of nitrogen.

\begin{tabular}{|c|c|c|c|c|c|c|c|}
\hline & \multicolumn{3}{|c|}{ Digestibility \% } & & \multicolumn{3}{|c|}{ Nitrogen \% } \\
\hline & DM & $\mathrm{CP}$ & CF & EE & $\begin{array}{c}\text { Ash } \\
\text { retention \% }\end{array}$ & Excreta & Feces \\
\hline & \multicolumn{7}{|c|}{ Effect of Diet } \\
\hline Control & 80.4 & 75.5 & 29.0 & 79.6 & 31.4 & $5.41^{\mathrm{a}}$ & 2.52 \\
\hline Low-CP & 81.3 & 77.5 & 31.4 & 79.9 & 32.6 & $5.05^{\mathrm{a}}$ & 2.37 \\
\hline \multirow[t]{2}{*}{ Low-CPME } & 80.5 & 77.1 & 31.2 & 80.5 & 32.6 & $5.09^{b}$ & 2.39 \\
\hline & \multicolumn{7}{|c|}{ Effect of Type of Phytase } \\
\hline FP & 82.3 & 78.0 & 33.1 & 80.7 & 33.0 & 5.08 & 2.26 \\
\hline \multirow[t]{2}{*}{$\mathrm{BP}$} & 82.0 & 78.2 & 32.3 & 80.7 & 33.3 & 5.04 & 2.27 \\
\hline & \multicolumn{7}{|c|}{ Interaction Diet $\times$ Phytase } \\
\hline Control & 80.4 & 75.5 & 29.0 & 79.6 & 31.4 & 5.41 & 2.52 \\
\hline Low-CP $\times$ Uns & 79.1 & 76.0 & 29.0 & 78.8 & 31.4 & 5.14 & 2.55 \\
\hline Low-CP $\times$ FP & 82.4 & 78.1 & 33.1 & 80.4 & 33.0 & 5.02 & 2.26 \\
\hline Low-CP $\times$ BP & 82.4 & 78.6 & 32.1 & 80.5 & 33.4 & 5.01 & 2.28 \\
\hline Low-CPME $\times$ Uns & 77.9 & 75.5 & 28.0 & 79.7 & 31.5 & 5.06 & 2.61 \\
\hline Low-CPME $\times$ FP & 82.1 & 78.0 & 33.1 & 81.0 & 33.0 & 5.14 & 2.26 \\
\hline Low-CPME $\times$ BP & 81.5 & 77.9 & 32.5 & 81.0 & 33.2 & 5.07 & 2.27 \\
\hline \multirow[t]{2}{*}{ SEM } & 0.59 & 0.45 & 0.90 & 0.91 & 0.44 & 0.09 & 0.04 \\
\hline & \multicolumn{6}{|c|}{$p$ Values } & \\
\hline Diet & NS & NS & NS & NS & NS & 0.01 & NS \\
\hline Phytase type & NS & NS & NS & NS & NS & NS & NS \\
\hline Interaction & NS & NS & NS & NS & NS & NS & NS \\
\hline
\end{tabular}

${ }^{\mathrm{a}}{ }^{\mathrm{b}}$ means within a column with different superscripts are significantly different $(p<0.05)$; FP—fungal phytase; BP— bacterial phytase; Uns - unsupplemented; SEM-standard error or mean; NS—not significant; low-CP-low crude protein diet; low-CPME—low crude protein and metabolizable energy diet.

The effects of diet and type of phytase on carcass traits are presented in Table 4 . Low-CP diets negatively affected $(p<0.01)$ the percentage of intestinal length compared to the control group but low-CPME diets showed no differences in comparison to the other two groups. The use of both phytases did not affect carcass traits. There was, for the percentage of abdominal fat, an effect of the interaction $(p<0.05)$ : broilers fed lowCPME diets had a higher percentage of abdominal fat when fungal phytase was added in comparison to the control group.

Tibia characteristics and concentrations of $\mathrm{Ca}$ and $\mathrm{P}$ in the blood plasma of broilers are presented in Table 5. No effects were observed due to diet CP and ME levels, and types of phytase. No effect of the interaction between the two main effects was observed for the data reported in Table 5.

The effect of diet and type of phytase on total protein, albumin, globulin, total lipids, cholesterol, alkaline phosphatase, and aspartate aminotransferase of the blood of slowgrowing broilers are reported in Table 6. Low-CP and low-CPME diets similarly increased $(p<0.01)$ the albumin than the control group. The use of both types of phytase did not affect the tested blood biochemistry. No effects of the interaction diet $\times$ type of phytase were observed. 
Table 4. Effect of diet, type of phytase, and their interaction on carcass traits and production index (\%) of broilers.

\begin{tabular}{|c|c|c|c|c|c|c|c|c|}
\hline & Dressing & AF & Liver & Pancreas & Spleen & Intestinal Lenght & Caecal Lenght & EPI \\
\hline & \multicolumn{8}{|c|}{ Effect of Diet } \\
\hline Control & 70.9 & 1.93 & 2.40 & 0.220 & 0.165 & $9.48^{\mathrm{a}}$ & 0.876 & 169 \\
\hline Low-CP & 68.4 & 2.18 & 2.10 & 0.200 & 0.171 & $8.18^{\mathrm{b}}$ & 0.938 & 158 \\
\hline Low-CPME & 69.7 & 2.28 & 2.17 & 0.230 & 0.162 & $8.73^{a, b}$ & 0.939 & 157 \\
\hline \multicolumn{9}{|c|}{ Effect of Type of Phytase } \\
\hline $\mathrm{FP}$ & 67.9 & 2.47 & 2.07 & 0.220 & 0.165 & 8.65 & 0.963 & 155 \\
\hline BP & 69.6 & 2.66 & 2.17 & 0.200 & 0.165 & 8.99 & 0.924 & 156 \\
\hline \multicolumn{9}{|c|}{ Interaction Diet $\times$ Phytase } \\
\hline Control & 70.9 & $1.93^{b}$ & 2.40 & 0.220 & 0.165 & 9.48 & 0.875 & 169 \\
\hline Low-CP $\times$ Uns & 68.6 & $1.68^{\mathrm{b}}$ & 1.92 & 0.212 & 0.169 & 7.55 & 0.989 & 162 \\
\hline Low-CP $\times$ FP & 67.1 & $2.02^{b}$ & 2.29 & 0.206 & 0.147 & 7.96 & 0.938 & 154 \\
\hline Low-CP $\times$ BP & 69.4 & $2.84^{\mathrm{a}, \mathrm{b}}$ & 2.08 & 0.179 & 0.197 & 9.02 & 0.885 & 155 \\
\hline Low-CPME $\times$ Uns & 70.6 & $1.44^{\mathrm{b}}$ & 2.05 & 0.249 & 0.154 & 7.91 & 0.868 & 161 \\
\hline Low-CPME × FP & 68.6 & $3.30^{\mathrm{a}}$ & 2.06 & 0.245 & 0.182 & 9.32 & 0.987 & 157 \\
\hline Low-CPME $\times$ BP & 69.9 & $2.10^{\mathrm{a}, \mathrm{b}}$ & 2.05 & 0.194 & 0.150 & 8.92 & 0.962 & 157 \\
\hline SEM & 1.20 & 0.379 & 0.147 & 0.020 & 0.018 & 0.489 & 0.056 & 5.71 \\
\hline & \multicolumn{8}{|c|}{$p$ Values } \\
\hline Diet & NS & NS & NS & NS & NS & 0.01 & NS & NS \\
\hline Phytase type & NS & NS & NS & NS & NS & NS & NS & NS \\
\hline Interaction & NS & 0.05 & NS & NS & NS & NS & NS & NS \\
\hline
\end{tabular}

${ }^{\mathrm{a}}, \mathrm{b}$ means within a column with different superscripts are significantly different $(p<0.05)$; FP—fungal phytase; BP— bacterial phytase; Uns—unsupplemented; SEM—standard error or mean; NS—not significant; low-CP-low crude protein diet; low-CPME-low crude protein and metabolizable energy diet; AF: abdominal fat; EPI- European production index.

Table 5. Effect of diet, type of phytase and their interaction on tibia characteristics, and plasma calcium and inorganic phosphorus of broilers.

\begin{tabular}{|c|c|c|c|c|c|c|c|}
\hline & \multicolumn{5}{|c|}{ Tibia Characterstics } & \multicolumn{2}{|c|}{ Plasma } \\
\hline & Lenght $\mathrm{mm}$ & Weight g & Diameter mm & Ash \% & Calcium \% & Phosphorus \% & Calcium mg/dL \\
\hline \multicolumn{8}{|c|}{ Effect of Diet } \\
\hline Control & 110 & 7.59 & 11.7 & 44.7 & 20.3 & 10.2 & 10.6 \\
\hline Low-CP & 110 & 8.01 & 11.4 & 44.7 & 20.6 & 10.2 & 11.2 \\
\hline Low-CPME & 109 & 8.06 & 11.5 & 44.9 & 20.8 & 10.4 & 11.3 \\
\hline \multicolumn{8}{|c|}{ Effect of Type of Phytase } \\
\hline FP & 110 & 8.32 & 11.5 & 44.9 & 20.8 & 10.3 & 11.6 \\
\hline $\mathrm{BP}$ & 111 & 7.98 & 11.8 & 45.2 & 20.9 & 10.4 & 11.9 \\
\hline \multicolumn{8}{|c|}{ Interaction Diet $\times$ Phytase } \\
\hline Control & 110 & 7.59 & 11.7 & 44.8 & 20.3 & 10.2 & 10.6 \\
\hline Low-CP $\times$ Uns & 108 & 7.52 & 10.6 & 44.5 & 20.4 & 10.1 & 10.3 \\
\hline Low-CP $\times$ FP & 112 & 8.65 & 11.9 & 44.7 & 20.5 & 10.1 & 11.5 \\
\hline Low-CP × BP & 111 & 7.87 & 11.7 & 45.0 & 20.8 & 10.3 & 11.8 \\
\hline Low-CPME $\times$ Uns & 109 & 7.92 & 11.4 & 44.1 & 20.2 & 10.1 & 10.0 \\
\hline Low-CPME × FP & 108 & 7.99 & 11.2 & 45.2 & 21.2 & 10.5 & 11.8 \\
\hline Low-CPME $\times$ BP & 111 & 8.10 & 11.2 & 45.4 & 20.9 & 10.5 & 12.1 \\
\hline SEM & 2.20 & 0.66 & 0.50 & 0.41 & 0.31 & 0.16 & 0.346 \\
\hline & \multicolumn{7}{|c|}{$p$ Values } \\
\hline Diet & NS & NS & NS & NS & NS & NS & NS \\
\hline Phytase type & NS & NS & NS & NS & NS & NS & NS \\
\hline Interaction & NS & NS & NS & NS & NS & NS & NS \\
\hline
\end{tabular}

FP—fungal phytase; BP, bacterial phytase; Uns—unsupplemented; SEM-standard error or mean; NS—not significant; low-CP—lowcrude protein diet; low-CPME-low crude protein and metabolizable energy diet. 
Table 6. Effect of diet, type of phytase, and their interaction on blood traits of broilers.

\begin{tabular}{|c|c|c|c|c|c|c|c|}
\hline & TP g/dL & Alb g/dL & Glob g/dL & TL mg/dL & Chol mg/dL & AP U/L & AST U/L \\
\hline & \multicolumn{7}{|c|}{ Effect of Diet } \\
\hline Control & 4.15 & $1.11^{\mathrm{b}}$ & 3.00 & 691 & 112 & 51.5 & 11.0 \\
\hline Low-CP & 3.91 & $1.53^{\mathrm{a}}$ & 2.39 & 700 & 115 & 52.2 & 10.9 \\
\hline \multirow[t]{2}{*}{ Low-CPME } & 4.00 & $1.47^{\mathrm{a}}$ & 2.63 & 687 & 106 & 51.2 & 10.8 \\
\hline & \multicolumn{7}{|c|}{ Effect of Type of Phytase } \\
\hline FP & 3.85 & 1.45 & 2.45 & 696 & 100 & 51.3 & 10.7 \\
\hline \multirow[t]{2}{*}{$\mathrm{BP}$} & 3.87 & 1.42 & 2.46 & 690 & 102 & 51.1 & 10.6 \\
\hline & \multicolumn{7}{|c|}{ Interaction Diet $\times$ Phytase } \\
\hline Control & 4.15 & 1.10 & 3.00 & 691 & 112 & 51.5 & 11.0 \\
\hline Low-CP $\times$ Uns & 4.04 & 1.51 & 2.54 & 712 & 141 & 52.6 & 11.0 \\
\hline Low-CP $\times$ FP & 4.08 & 1.59 & 2.49 & 698 & 106 & 53.0 & 10.9 \\
\hline Low-CP $\times$ BP & 3.61 & 1.47 & 2.14 & 690 & 99.5 & 51.0 & 10.7 \\
\hline Low-CPME $\times$ Uns & 4.24 & 1.53 & 2.71 & 677 & 120 & 52.7 & 11.3 \\
\hline Low-CPME $\times$ FP & 3.63 & 1.47 & 2.43 & 693 & 94.4 & 49.6 & 10.7 \\
\hline Low-CPME $\times$ BP & 4.14 & 1.38 & 2.76 & 689 & 104 & 51.2 & 10.4 \\
\hline \multirow[t]{2}{*}{ SEM } & 38.7 & 0.059 & 0.212 & 8.101 & 6.70 & 8.20 & 0.270 \\
\hline & \multicolumn{6}{|c|}{$p$ Values } & \\
\hline Diet & NS & 0.0001 & NS & NS & NS & NS & NS \\
\hline Phytase type & NS & NS & NS & NS & 0.0001 & NS & NS \\
\hline Interaction & NS & NS & NS & NS & NS & NS & NS \\
\hline
\end{tabular}

${ }^{\mathrm{a}}{ }^{\mathrm{b}}$ means within a column with different superscripts are significantly different $(p<0.05)$; FP—fungal phytase; BP- bacterial phytase; Uns-unsupplemented; SEM, standard error or mean; NS—not significant. Low-CP, low crude protein diet; low-CPME, low crude protein and metabolizable energy diet; TP—total protein; Alb—albumin; Glob—globulin; TL—total lipids; Chol—cholesterol; AP—alkaline phosphatase; AST—aspartate aminotransferase.

\section{Discussion}

\subsection{Effect of Protein and Energy Level in the Diet}

Reducing protein and energy levels in the diets did not affect the body weight gain and thus, the final weight of slow-growing broilers, showing that all the diets used in the trial were adequate to sustain the growth of colored broilers of Sasso strain from 1 to $64 \mathrm{~d}$ of age. This happened even if the feed, protein, and energy intake were reduced in both low-CP and low-CPME diets, and can be explained as the protein and energy conversion ratios were increased when $\mathrm{CP}$ and $\mathrm{ME}$ levels were reduced in the diets. Our results are in line with Khalifah [18], who found no significant differences on BW of slow-growing broilers when diets with 18,16 or $14 \%$ CP were administered. Attia et al. [19] indicated that the protein effect is age-dependent since it has a significant impact on BW of chickens at 4 weeks of age, but no effects were observed later on. However, the increase in protein and energy conversion ratios is not tied to an increase of protein or metabolizable energy digestibility. Similarly, Attia et al. [20] and Shaldam [21] found no improvement in crude protein, ether extract, crude fiber, and ash digestibility due to decreasing protein and energy levels in broiler diets. Probably, the effect on nutrient digestibility is tied to the level of protein and/or energy reduction: in our trial, lowering 1 point percentage and $100 \mathrm{Kcal}$ of protein and metabolizable energy, respectively, did not affect the digestibility coefficients of the nutrients. The decrease of nitrogen percentage in poultry excreta due to low- $\mathrm{CP}$ and low-PME diets (6.7\%) is due to the reduction of ingested protein (5\%). On the other hand, Abd-Elsamee [22] indicated that decreasing dietary crude protein significantly increased $\mathrm{OM}^{\prime}$ 's digestibility coefficients, $\mathrm{CP}, \mathrm{EE}$, and nitrogen retention. It is not easy to explain the reduction of the intestine length recorded in poultry fed a low-CP diet, as no similar evidence is reported in the literature. Decreasing CP and CP + ME levels also caused an unexplained increase in plasma albumin without serum total protein changes. However, the most important result is that lowering $\mathrm{CP}$ and $\mathrm{ME}$ in diets reduced the feeding cost. 
Considering that feeding cost is the highest cost in livestock production, this reduction also lowered the total cost of broiler production. Both reductions of energy and protein $(4.1 \%)$ were more effective than the reduction of protein alone $(2.5 \%)$. The decrease in feeding costs can be associated with either lower feed consumption, and/or lower prices of feed with lower nutritional value when acceptable performance was maintained.

\subsection{Effect of Phytase Supplementation and Type}

Otherwise, the diet, the effect of type of phytase in feed intake reduction (and thus in protein and energy intake reduction) can be explained due to the increase of nutrient digestibility (dry matter $+3.8 \%$; crude fiber $+13.9 \%$; crude protein $+3.2 \%$; ash retention $+8.3 \%)$ and the decrease of nitrogen percentage in the feces $(-12.1 \%)$. These results agree with Attia et al. [23], who found that phytase can improve the utilization of tropical native crops in laying hens. Besides, Ennis et al. [8] and Al-Harti et al. [24] found an improvement in nutrient digestibility and growth performance in broilers supplemented with microbial phytase. Even if the increase in nutrient digestibility was similar for both phytases, the impact on animal performance was different as bacterial phytase was more effective than fungal phytase in feed (5.5 vs. $3.2 \%)$, protein ( 7.2 vs. $4.9 \%)$, and energy (6.1 vs. 3.7\%) intake reduction. The effect of phytase on CP digestibility could be attributed to an improvement in the amino acid's digestibility. Farrell et al. [25] indicated that phytase supplementation improved nitrogen retention by $2.7 \%$ and MEn by $2.3 \%$, and this partly reflects the increase of DM and true ileal amino acid digestibility. Similar results were obtained by Attia et al. [1] and Rutherfurd et al. [26] when microbial phytase was supplemented to the diets. The surprising finding in this research was the positive effect of phytase on apparent digestibility of crude fiber. This could suggest further positive effects such as the increase of ME value of the diets [1,20,27]. Johnson et al. [28] observed an improvement of fiber digestibility when 4500 FTU of an E. coli phytase were supplemented to broiler diets. The different effects of type of phytase on nutrient intake could be ascribed to the different characteristics of the two enzymes. In fact, fungal and bacterial phytase have different optimal $\mathrm{pH}$ and resistance to pepsin which can affect the amount of digested and degraded phytase in the upper gastro-intestinal tract of poultry [29].

Several authors $[15,30,31]$ showed that phytase supplementation to broiler, duck, and Japanese quail diets did not affect plasma protein, lipids, and cholesterol. In literature, the effect of phytase on tibia ash and mineral contents depends on the type of enzyme: In fact, E. coli phytase had a stronger effect than the fungal phytase-3 [32]. On the contrary, Jendza et al. [33] and Pillai et al. [34] observed that the source of phytase did not affect tibia ash. Along the same line, Payne et al. [35] and Veum et al. [36] did not observe differences between E. coli and P. Lycii phytase in bone-breaking strength, ash weight, and apparent absorption (g/d and \%) of $\mathrm{P}, \mathrm{Ca}, \mathrm{Mg}, \mathrm{Zn}, \mathrm{Fe}$, and $\mathrm{Cu}$ when used at $500 \mathrm{U}$. This probably happens because, although feed intake decreased due to the use of phytases, the enzymes supplied a higher amount of phosphorus and calcium as confirmed by their higher levels in blood. El-Deeb et al. [37] showed that broilers fed diets supplemented with phytase had serum inorganic phosphorus concentration similar than the positive control. Attia et al. [1] found that phytase supplementation increased plasma P of broilers fed diets with suboptimal levels of CP and ME. Perney et al. [38] reported that phytase supplementation to a maize-soybean meal diet containing less phosphorus than NRC's recommended level [11] increased tibia ash and plasma P of broilers. Rodehutscord and Pfeffer [39] found that blood serum phosphate, but not Ca, increased when phytase was supplemented to duck diets. The increase in plasma $\mathrm{P}$ observed in our trial can be ascribed to an increase in its digestibility: On this regard, Mireles-Arriaga et al. [40] have shown increased digestibility of total phosphorus from 35.81 to $15.87 \%$ due to the addition of phytase in broiler diets.

In our study, a few differences are between the two types of phytases; in particular, 6-E. coli phytase reduced feed intake, protein, and energy intake. Our results are according to Ptak et al. [41], who found that bacterial phytase from E. coli strongly reduced feed intake 
than phytase from A. niger than the control. Our results can be explained as the 6-phytase needs to deplete a greater proportion of the phytate pool for equivalent phosphorus release compared to 3-phytase [10]; therefore, the energy and amino acids' units obtained per unit of 6-phytase activity are larger than 3-phytases. This can induce a higher amount of nutrient availability and thus, a reduced feed intake. As a direct consequence of lowering feed intake, the use of phytase reduces the feeding and total costs with greater effects due to the use of bacterial phytase.

\subsection{Effect of the Interaction Diet $\times$ Type of Phytase}

Considering the number of criteria considered in our trial, just some of them were significantly affected by the interaction diet $x$ type of phytase (feed, protein and energy intake, and abdominal fat), and this suggests that the two types of phytase, in general, act in the same way in both diets. This agrees with several authors, including Qota et al. [30] and Attia [20].

Mortality rate was not different among the experimental group, suggesting no effect on types of diet and/or phytase supplementation. The overall incidence of mortality $1 \%$ was in normal range for broilers $[22,24,30]$. It should be mentioned that the feed intake was corrected for differences in mortality among pens and treatments, and thus the FCR was based corrected/actual feed consumption among the experimental treatments. However, there were still in-avoided cases which cannot be corrected, such as variation in space allowance and thus bird's activity, and it has an effect on energy expenditure and increasing feeding space in the pens.

\section{Conclusions}

The use of phytase, independently from its source, allows reducing the protein and energy content of $\mathrm{Ca}$ and $\mathrm{P}$ adequate diets for colored broilers of Sasso strain during 1-64 days of age. The use of 6-E. coli phytase induced the lowest feed intake without adverse effects on the body weight gain of broiler and improvements of feed conversion ratio. The supplementation of $A$. niger increased abdominal fat deposition of compared lowCPME diet compared to low-CPME_uns diet. All diets showed similar production index allowing the use of low-CPME diet when phytases were supplemented. In addition, the decrease of the nitrogen content in the feces could be a very important finding concerning the reduction of the environmental burden.

Author Contributions: Conceptualization, Y.A.A., and A.E.-R.E.T.E.-D.; methodology, W.S.S., Y.A.A., and F.B.; software, F.B.; validation, M.A.A.-H.; formal analysis, F.B.; investigation, W.S.S.; Y.A.A., and F.B.; writing —original draft preparation, F.B., and M.A.A.-H.; writing-review and editing, Y.A.A., and A.E.-R.E.T.E.-D.; supervision. All authors have read and agreed to the published version of the manuscript.

Funding: This research received no external funding.

Institutional Review Board Statement: The experimental procedures were approved by the Ethical Animal Care and Use Committee of the Department of Veterinary Medicine and Animal Production of the University of Napoli Federico II, Italy (prot. N. 2017/0017676).

Informed Consent Statement: Not applicable.

Data Availability Statement: Data can be available requiring via email to prof. Youssef A. Attia, yaattia@kau.edu.sa.

Conflicts of Interest: The authors declare no conflict of interest. 


\section{References}

1. Attia, Y.A.; Abd El-Rahman, S.A.; Qota, E.M.A. Effects of microbial phytase with or without cell-wall splitting enzymes on the performance of broilers fed suboptimum levels of dietary protein and metaboilzable energy. Egypt. Poult. Sci. 2001, 21, 521-547.

2. Macelline, S.P.; Wickramasuriya, S.S.; Cho, H.M.; Kim, E.; Shin, T.K.; Hong, J.S.; Kim, J.C.; Pluske, J.R.; Choi, H.J.; Hong, Y.G.; et al. Broilers fed a low protein diet supplemented with synthetic amino acids maintained growth performance and retained intestinal integrity while reducing nitrogen excretion when raised under poor sanitary conditions. Poult. Sci. 2020, 99, 949-958. [CrossRef] [PubMed]

3. Liu, S.Y.; Macelline, S.P.; Chrystal, P.V. Progress towards reduced-crude protein diets for broiler chickens and sustainable chicken-meat production. J. Anim. Sci. Biotechnol. 2021, 12. [CrossRef]

4. Dayyani, N.; Abadi, M.B.B.; Farhani, A.A.A. Phytate and phytase in poultry nutrition. Int. J. Adv. Biol. Biomed. Res. 2013, 1, 1403-1408.

5. Lu, H.; Shin, S.; Kuehn, I.; Bedford, M.; Rodehutscord, M.; Adeola, O.; Ajuwon, K.M. Effect of phytase on nutrient digestibility and expression of intestinal tight junction and nutrient transporter genes in pigs. J. Anim. Sci. 2020, 98, 206. [CrossRef]

6. Ren, P.; Blavi, L.; González-Vega, C.; Liu, Y.; Hancock, D.; Vazquez-Añón, M.; Almeida, F.A.; Stein, H.H. Effects of a novel E. coli phytase expressed in Pseudomonas fluorescens on growth, bone mineralization, and nutrient digestibility in pigs fed corn-soybean meal diets. Transl. Anim. Sci. 2020, 4. [CrossRef]

7. Babatunde, O.O.; Jendza, J.A.; Ader, P.; Xue, P.; Adedokun, S.A.; Adeola, O. Response of Broiler Chickens in the Starter and Finisher Phases to 3 Sources of Microbial Phytase. Poult. Sci. 2020, 99, 3997-4008. [CrossRef]

8. Ennis, C.E.; Jackson, M.; Gutierrez, O.; Cantley, S.; Wamsley, K.G.S. Phytase and carbohydrase inclusion strategies to explore synergy within low-energy diets to optimize 56-day male broiler performance and processing. J. Appl. Poult. Res. 2020, 29, 1045-1067. [CrossRef]

9. Żyła, K.; Mika, M.; Stodolak, B.; Wikiera, A.; Koreleski, J.; Świątkiewicz, S. Towards complete dephosphorylation and total conversion of phytases in poultry feeds. Poult. Sci. 2004, 83, 1175-1186. [CrossRef] [PubMed]

10. Bedford, M.R.; Cowieson, A.J. Phytase and phytate interactions. In Proceedings of the 17th European Symposium on Poultry Nutrition, Edinburgh, Scotland, 23-27 August 2009.

11. NRC. National Research Council, Nutrient Requirements of Poultry, 9th ed.; National Academy Press: Washington, DC, USA, 1994.

12. Association of Official Analytical Chemists, AOAC. Official Methods of Analysis of the Association of Official Analytical Chemists, 18th ed.; AOAC: Washington, DC, USA, 2004.

13. Attia, Y.A.; El-Tahawy, W.S.; Abd El-Hamid, A.E.; Hassan, S.S.; Nizza, A.; El-Kelaway, M.I. Effect of phytase with or without multienzyme supplementation on performance and nutrient digestibility of young broiler chicks fed mash or crumble diets. It. J. Anim. Sci. 2012, 11, 303-308. [CrossRef]

14. Jakobsen, P.E.; Gertov, K.; Nilsen, S.H. Frdjelighed frogmed fierbrae. Digestibility trails with poultry. Bereting fra for sogslabortoriet. Kabenhaven 1960, 56, 1-34.

15. Attia, Y.A.; Qota, M.A.; Bovera, F.; Tag El-Din, A.E.; Mansour, S.A. Effect of amount and source of manganese and/or phytase supplementation on productive and reproductive performance and some physiological traits of dual purpose cross-bred hens in the tropics. Br. Poult. Sci. 2010, 51, 235-245. [CrossRef] [PubMed]

16. Attia, Y.A.; Al-Hanoun, A.; Tag El-Din, A.E.; Bovera, F.; Shewika, E. Effect of bee pollen levels on productive, reproductive and blood traits of NZW rabbits. J. Anim. Physiol. Anim. Nutr. 2011, 95, 294-303. [CrossRef]

17. SAS Institute. SAS®User's Guide: Statistics; SAS Institute Inc.: Cary, NC, USA, 2002.

18. Khalifah, M.M. Effect of Protein, Energy and Feeding System on the Performance of Two Local Chicken Strains. Ph.D. Thesis, Faculty of Agriculture Tanta University, Gharbia, Egypt, 2001.

19. Attia, Y.A.; Bovera, F.; Al-Harthi, M.A.; Wang, J.; Kim, W.K. Multiple amino acid supplementations to low dietary protein diets: Effect on performance, carcass yield, meat quality and nitrogen excretion of finishing broilers under hot climate conditions. Animals 2020, 10, 973. [CrossRef]

20. Attia, Y.A.; Hassan, S.S. Broiler tolerance to heat stress at various dietary protein/energy levels. Europ. Poult. Sci. 2017, 81. [CrossRef]

21. Shaldam, M.D.A. Studies of some Factors Affecting Meat Production any Improved Local Strains. Master's Thesis, Al-Azhar University, Cairo, Egypt, 2003; pp. 3-17.

22. Abd-Elsamee, M.O. Effect of different levels of crude protein, sulphur amino acids, microbial phytase and their interaction on broiler chicks performance. Egypt. Poult. Sci. 2002, 22, 999-1021.

23. Attia, Y.A.; Al-Hamid, A.E.A.; Ibrahim, M.S.; Al-Harthi, M.A.; Bovera, F.; Elnaggar, A.S. Productive performance, biochemical and hematological traits of broiler chickens supplemented with propolis, bee pollen, and mannan oligosaccharides continuously or intermittently. Livest. Sci. 2014, 164, 87-95. [CrossRef]

24. Al-Harthi, M.A.; Attia, Y.A.; El-Shafey, A.S.; Elgandy, M.F. Impact of phytase on improving the utilisation of pelleted broiler dietscontaining olive by-products. It. J. Anim. Sci. 2020, 19, 310-318. [CrossRef]

25. Farrell, D.J.; Martin, E.D.; Paeez, J.J.; Bongarts, M.; Betts, M.; Sideman, A.; Thomson, E. The beneficial effects of a microbial feed phytase in diets of broiler chickens and ducklings. J. Anim. Physiol. Anim. Nutr. 1993, 69, 278-283. [CrossRef]

26. Rutherfurd, S.M.; Chung, T.K.; Morel, P.C.; Moughan, P.J. Effect of microbial phytase on ileal digestibility of phytate phosphorus. Poult. Sci. 2004, 83, 61-68. [CrossRef] [PubMed] 
27. El-Ghamry, A.A.; Al-Harthi, M.A.; Attia, Y.A. Possibility to improve rice polishing utilization in broiler diets by enzyme or dietary formulation based on digestible amino acid. Archiv. Geflügelk. 2005, 69, 1-8.

28. Johnson, L.A.; Deep, A.; Classen, H. Digestibility and performance responses of broiler chickens fed a pea-based diet with different levels of dietary microbial phytase. Univ. Sask. Undergrad. Res. J. 2014, 1, 39-44. [CrossRef]

29. Yu, B.; Jana, Y.C.; Chungb, T.K.; Leea, T.T.; Chioua, P.W.S. Exogenous phytase activity in the gastrointestinal tract of broiler chickens. Anim. Feed Sci. Technol. 2004, 117, 295-303. [CrossRef]

30. Qota, E.M.A.; El-Ghamry, A.A.; El-Mallah, G.M. Nutritive value of soaked linseed cake as affected by phytase, Biogen supplementation or formulating diets based on available amino acid on broiler performance. Egypt. Poult. Sci. 2002, 22, 461-475.

31. Ismail, F.S.A.; Attia, Y.A.; Aggoor, F.A.M.; Qota, E.M.A.; Shakmak, E.A. Effect of energy level, rice by products and enzyme additions on carcass yield, meat quality and plasma constituents of Japanese quail. In Proceedings of the XII European Poultry Conference, Verona, Italy, 10-14 September 2006.

32. Augspurger, N.P.; Baker, D.H. High dietary phytase levels maximize phytate-phosphorus utilization but do not affect protein utilization in chicks fed phosphorus or amino acid-deficient diets. J. Anim. Sci. 2004, 82, 1100-1107. [CrossRef]

33. Jendza, J.A.; Dilger, R.N.; Sands, J.S.; Adeola, O. Efficacy and equivalency of an Escherichia coli-derived phytase for replacing inorganic phosphorus in the diets of broiler chickens and young pigs. J. Anim. Sci. 2006, 84, 3364-3374. [CrossRef]

34. Pillai, P.B.; Connor-Dennie, T.O.; Owens, C.M.; Emmert, J.L. Efficacy of an Escherichia coli phytase in broilers fed an adequate or reduced phosphorus diets and its effect on carcass characteristics. Poult. Sci. 2006, 85, 1737-1745. [CrossRef] [PubMed]

35. Payne, R.L.; Lavergne, T.K.; Southerm, L.L. A comparison of two sources of phytase in liquid and dry forms in broilers. Poult. Sci. 2005, 84, 265-272. [CrossRef]

36. Veum, T.L.; Bllinger, D.W.; Buff, C.E.; Bedford, M.E. A genetically engineered Escherichia coli phytase improves nutrient utilization, growth performance, and bone strength of young swine fed diets deficient in available phosphorus. J. Anim. Sci. 2006, 84, 1147-1158. [CrossRef]

37. El-Deeb, M.A.; Sharara, H.H.; Makled, M.N. Enhance calcium and phosphorus utilization by enzyme phytase supplemented to broiler diet contained rice bran. Egypt. Poult. Sci. 2000, 20, 545-566.

38. Perney, K.M.; Cantor, A.H.; Straw, M.L.; Herkelman, K.L. The effect of dietary phytase on growth performance and phosphorus utilisation of broiler chicks. Poult. Sci. 1993, 72, 2106-2114. [CrossRef] [PubMed]

39. Rodehutscord, M.; Pfeffer, E. Phytase effects on the efficiency of utilization and blood concentrations of phosphorus and calcium in Pekin ducks. Br. Poult. Sci. 2006, 47, 311-321. [CrossRef] [PubMed]

40. Mireles-Arriaga, A.I.; Espinosa-Ayala, E.; Hernández-García, P.A.; Márquez-Molina, O. Use of Exogenous Enzyme in Animal. Feed Life Sci. J. 2015, 12, 23-32.

41. Ptak, A.; Damian, J.; Bartosz, K.; Mateusz, R.; Krzysztof, Ż.; Sylwester, Ś. Effect of different phytases on the performance, nutrient retention and tibia composition in broiler chickens. Archiv. Anim. Breed. 2013, 56, 104-112. [CrossRef] 